RESEARCHARTICLE

\title{
"Who can tell me what the product actually means, and Kate's got the right answer-ish, let's just tweak it..." Follow-up strategies in the U.K primary school classroom: Does teacher gender matter?"
}

\author{
Joanne McDowell*
}

English Language and Linguistics, University of Hertfordshire, UK

Abstract

Jobs are rarely seen as gender neutral but built on gendered stereotypes as to what they involve, and the gendered characteristics assumed needed to perform them. Despite an increase in the number of women entering 'male' workplaces, gendered occupational stereotypes continue to endure as they are so deeply entrenched within community. Furthermore, even with frequent government initiatives, men's numbers are not increasing in 'female' occupations such as teaching as these jobs persistent to be seen as only suitable for those with 'feminine' characteristics. Fewer than 15 percent of United Kingdom (U.K.) primary school teachers are male. De-stereotyping this work role is therefore of key importance as we need more qualified teachers in the U.K. To date, there has been relatively little research into the linguistic behaviour of men working in primary school teaching. To address this gap, this current paper focuses on men's discursive behaviour in the occupation of teaching in an attempt to begin to de-stereotype this profession through an exploration of how the job is actually performed through language to assess whether teacher gender affects teaching strategies utilised in the classroom. This paper reports on the qualitative findings from an exploratory case study that examines male and female primary school teachers' linguistic strategies in teacher-led class instruction. To provide empirical insights into how this work-role practice is performed, this paper focuses on the oral feedback given by the teacher to pupils to examine how they use follow-up strategies. Data collected by 12 teachers across 4 schools in Hertfordshire in the U.K. was explored using Interactional Sociolinguistics and a social constructionist perspective. Results demonstrate both female and male teachers actively constructing a context-dependent teaching identity, with their language breaking stereotypical gendered norms of speaking. The discursive behaviour of these teachers should therefore not be described as 'feminine' or 'masculine', but rather labelled as the discourse of doing 'being' a teacher. They are using the unmarked speech styles in this environment as the work role guides, shapes and permeates their discursive choices. Arguably then, gender is not an overriding variable here in being a teacher. These findings lend support to the current ongoing debate for the imperative need to de-gender how we think about language use, occupations, and the skills and characteristics one is assumed to have simply because of their gender. Men often decide against becoming a primary teacher because they think it is a female profession. We must re-interpret language use as reflecting professional identity rather than gender identity. By raising awareness of primary school teachers' linguistic behaviour, we may start to take steps towards de-gendering the job for only then may we see more men taking up such professional occupations. This research has important implications for U.K government incentives which currently try to recruit men by stressing that they are needed for hegemonic 'masculine' reasons, which only serves to strengthen gender stereotypes.

Corresponding author: Joanne McDowell, Principal lecturer, English Language and Linguistics, University of Hertfordshire, UK E-mail:j.mcdowell@herts.ac.uk 


\section{Keywords}

Gendered stereotypes; primary school teachers; interactional sociolinguistics; follow-up strategies; men

\section{Introduction}

The concept of gendered occupations emerges from the skills and characteristics that men and women are assumed to embody due to their sex, and what is deemed as 'feminine' or 'masculine' traits. This phenomenon is found on an international level (Didham, 2015; Huppatz \& Goodwin, 2013; Ku, 2011; Litosseliti \& Leadbeater, 2013; McEntee-Atalianis \& Litosseliti, 2017; Schnurr, 2013; Holmes \& Marra, 2017) and is extremely persistent. Men and women are believed to have a set of gendered characteristics (behaviours, traits, skills), and seen to be different based in line with these stereotypes (Carli, Alawa, Lee, Zhao \& Kim, 2016). Despite an increase in the number of women entering occupations once traditionally assigned to men, stereotypes continue to endure as they are so deeply entrenched in all communities (Haines, Deaux \& Lofaro, 2016). Feminine workplaces are consistently characterised by stereotypical features of femininity (being caring, facilitative, supportive) and masculine workplaces with masculinity (aggressiveness, competitiveness, power) (Burke \& Collins, 2001; Litosseliti \& Leadbeater, 2013; Malini \& Sood, 2016; Rhoton, 2011; Wasserman, Dayan \& Ben-Ari, 2018). Furthermore, men's numbers are not increasing in 'female' occupations, and in some countries, they are decreasing (McGrath \& Van Bergen, 2017a). Because of gender stereotyping, men often feel deterred from taking up a wide range of occupations that are considered 'female' (Bhana \& Moosa, 2016; Haines et al 2016; van der Vleuten, Jaspers, Maas \& van der Lippe, 2016; Mistry \& Sood, 2015; Moosa \& Bhana, 2017a, 2017b; Simpson, 2004; Thornton \& Bricheno, 2006; Vervecken, \& Hannover, 2015; Williams, 1993). This trend is evident both in countries within and outside the European Union (Buschor et al, 2014; Cruickshank, Pedersen, Cooley \& Hill, 2018; Huppatz \& Goodwin, 2013; Skelton, 2009).

Due to the near-absence of men in U.K primary school teaching, and the recurrent stereotypes that surround male teachers (e.g. they teach and discipline pupils differently to females),the research aim of this current paper is to examine the linguistic teaching practices in U.K primary-school classrooms of male and female teachers, specifically how they use follow-up teaching strategies with their pupils, to investigate whether teacher gender makes any difference. Primary schools in the U.K have been chosen due their remarkably low number of male primary school teachers, despite numerous government initiatives to increase men in this role. Through an exploratory case study of 6 male and 6 female teachers' language, this qualitative research demonstrates how they all use similar follow-up linguistic strategies to perform their work role. It is arguable then that the choice of language is not dependent on the interactants' gender, but their professional identity. It is imperative that we focus on the gendered discourses that continue to construct this area of work as 'women's work' because these discourses on assumed gender differences of women as 'carers/ nurturers' and 'superior communicators' have consequences that go beyond language (i.e. gender bias [Malini \& Sood, 2016; Carli et al, 2016; Haines, Deaux \& Lofaro, 2016]). Therefore, the empirical findings in this paper can be of key importance to shifting how we think about professions as gendered, to de-gendered. They could be an aid to the beginnings oferadication of gender bias from how we think about certain jobs or roles within the workplace; and the people we think are suitable to perform them (Cruickshank et al, 2018; Schnurr \& Zayts, 2017; Carli et al, 2016; Haines, Deaux \& Lofaro, 2016; Didham, 2015). Such findings may help challenge misconceptions about gendered behaviour in said workplaces which could in turn help recruitment efforts to address the world-wide shortage of men in 'feminine' occupations.

This paper adopts a social-constructionist and Interactional Sociolinguistics approach to investigate teaching discourse in the classroom to discuss the applicability of gendered speech stereotypes to this context. It begins with a discussion of teacher gender and the primary school before moving on to outline methods of data collection and analysis. Main results are then presented followed by an in-depth discussion and conclusions.

\section{Teacher Gender and The Primary School}

In the U.K, female staff composition comprises over 85 percent of registered primary school 
teachers, making the small proportion of primary schools in which male teachers are present interesting cases to study (Department of Education, 2016). Primary school teaching is seen to be a feminized role, deemed as appropriate only for those with feminine characteristics (Britton, 2000; Buschor et al., 2014). Therefore, this is a job role not seen as gender neutral but is instead defined in opposition to masculinity (Thornton \& Bricheno, 2006; Vervecken \& Hannover, 2015; Williams, 1993). Despite persistent efforts, key targets for male recruitment (and retention) in primary teaching are repeatedly not being met across many countries (Cruickshank et al., 2018; McGrath \& Van Bergen, 2017a). There may be a multitude of barriers that are causing this phenomenon, one such being the perceived low status of 'female' occupations. The few men who do work as primary teachers often report facing numerous challenges, as men who step out of the socially appropriate construct for their gender by entering 'female' professions are often 'marked', seen as deviant from the mainstream. Such challenges include the low pay, receiving homophobic comments and slurs of being a sexual predator, and not wanting to work with women or under female bosses (Allan, 1993; Bradley, 1993; Britton, 2000; Huppatz \& Goodwin, 2013; Lupton,2006; van der Vleuten et al., 2016). The low pay barrier also interlinks with the low status that 'female' work is often attributed: women's work activities are perceived to be of much lesser value than men's (Eckert \& McConnell-Ginet, 2003). Indeed, there is a commonly found rhetoric found amongst teachers themselves that primary school teaching is boring, undemanding, and unchallenging (Bhana \& Moosa, 2017b). This devaluation means that men entering primary teaching initiate a challenge to the traditional ideas of what is appropriate gender behaviour (Mistry \& Sood, 2015; Moosa \& Bhana, 2017a), so male primary teachers are often seen as not a 'real' man, or 'less' of a man (Sargent, 2000). Arguably, all these issues may be caused by one major factor; prevailing gendered stereotypes of what this work role entails, and the gendered characteristics assumed necessary to adequately perform said role.

There is anemergent body of work that examines men in this occupation, as well as a growing number of government incentives trying to recruit more men as there is a strong belief that more male teachers will decrease boy pupils' underachievement (Bullough, 2015; Cruickshank et al., 2018; Mistry \& Sood, 2015; Sargent, 2000). However, the latter clearly attempt to attract men by emphasising the 'masculine traits' of the role, which promotes stereotypical hegemonic masculine characteristics (e.gs men are needed to discipline, to be an authoritative male role model, they are presumed to have better relationships with boys and are ascribed the role of 'fathers') (Read, 2008; Spilt, Koomen \& Jak, 2012). Yet many male teachers have personally reported not feeling comfortable demonstrating the hegemonic masculine characteristics expected of them (Jones, 2004; Sargent, 2000; Skelton, 2009). Furthermore, such incentives explicitly imply that men are needed as they bring something to the profession that women simply cannot offer (discipline, control); but are not capable of giving care and nurture as these are not hegemonic masculine characteristics (Brundrett; DeSalis, Rowley \& Stokell, 2018). These recruitment drives are arguably failing as they are recurrently based on gendered beliefs. Research into primary school teaching from a wide range of disciplines has demonstrated that the empirical evidence does not support the aforementioned existing 'masculine' gendered beliefs and behaviours (Bullough, 2015; Carrington, Francis, Hutchings, Skelton, Read \& Hall 2007; Carrington, Tymms \& Merrell, 2008; Didham, 2015; Lahelma, 2000; McDowell \& Klattenberg, 2018; McGrath \& Van Bergen, 2017b; Read, 2008; Skelton, 2002, 2003; Spilt et al., 2012; Thornton \& Bricheno, 2006). Yet we repeatedly see incentives to increase and retain men centred around promoting hegemonic masculine characteristics and the 'male role model' myth (Brundrett et al., 2018; McGrath \& Van Bergen, 2017a; Sargent, 2000). It is therefore becoming increasingly important to de-gender attitudes towards the teaching profession and towards the skills and characteristics that are repeatedly seen to be gendered to perform this role. By doing so, we may recruit more men, not because of the persistent view that men bring something to the job that women cannot, but instead because we need a) a pool of good teachers and b) boys need to see men performing such roles to show them that they too can work in similar occupations themselves, to really begin to challenge gender-role stereotypes.

One way to change perceptions of primary teaching is through an exploration of what goes on in such workplaces by examining how the job is performed through language rather than simply assume male and female teachers will teach and discipline differently because of their gender. Indeed, one persistent gendered characteristic is that of linguistic behaviour. However, linguistic studies have now moved on to place focus on context rather than 
differences between the sexes and have found that men and women often employ the same speech style which is actually dependent on their workplace (Angouri, 2011; Eckert \& McConnell-Ginet, 1999; Holmes \& Marra, 2005, 2014,2017; Marsden \& Holmes, 2014; McDowell, 2018, 2015a, 2015b; Mullany, 2014; Schnurr, 2013). These stereotypes are still a very useful resource for study (Mullany \& Yoong, 2018) as they demonstrate the 'deeply entrenched stereotypical norms of women's and men's speech styles' that still exist today (Mills \& Mullany, 2011, p53).

Table 1. Widely cited features of 'feminine' and 'masculine' interactional style

\begin{tabular}{|l|l|}
\hline Feminine interactional style & Masculine interactional style \\
\hline Facilitative & Competitive \\
\hline Supportive feedback & Aggressive interruptions \\
\hline Conciliatory & Confrontational \\
\hline Indirect & Direct \\
\hline Collaborative & Autonomous \\
\hline Minor contribution (in public) & Dominates (public) talking time \\
\hline Person/process orientated & Task/outcome-oriented \\
\hline Affectively orientated & Referentially oriented \\
\hline
\end{tabular}

(Source: Holmes, 2006, pp.6)

In reality, language does not index gender (Cameron, 2007; Ochs, 1992), but instead, gender has been linked to speech styles that are thought to be used by men or women and it is this regular association that has created stereotypical gendered expectations. Therefore, it is often thought that the 'other' will not be able to perform in contexts in which they do not 'belong' (MacDougall, 1997; Mills \& Mullany, 2011). Gendered stereotyping is on the increase despite more women entering non -traditional areas (Haines et al., 2016). It is these stereotypes that we must address, as it could be precisely this that prevents men entering 'female' domains.

There are limited studies which have investigated the potential effect of teacher gender on primary classroom interaction (see McDowell \& Klattenberg, 2018; Read, 2008). One area of teaching regarding teacher gender that has been largely ignored is how teachers deliver oral feedback via their follow-up strategies (Good, Sikes \& Brophy, 1973). Therefore, this current paper will focus on the oral feedback given to pupil's in-class led instruction by examining the follow-up strategies in relation to teacher gender to provide empirical insights into how this work-role practice is performed.

\section{Focusing On 'Follow-Up'}

In interaction, 'repair' is often classified as joint work on a communication problem that must be overcome otherwise the conversation may collapse (Schegloff, Jefferson \& Sacks, 1977). Within the classroom, repair lies within the 'follow-up' move (originally termed 'feedback' by Sinclair and Coulthard [1975] in their Interaction-Response-Feedback exchange). It is this ' $F$ ' component of the IRF exchange that is claimed to differentiate classroom discourse from everyday conversational interaction (McHoul, 1990). 'Follow-up' is now seen to embrace the 'feedback' move, as feedback is only one function of follow-up (Cullen, 2002). In fact, followup can act an as umbrella term for evaluative feedback (implicit or explicit) as well as different types of repair strategies. Teachers have a wide range of follow-up strategies that they can employ (Vehkakoski, 2010). Follow up in the classroom comes more often in the form of repair, where the teacher's responses are directed toward the utterances made by the learner which contain an error (Ellis, Loewen \& Erlam, 2006). The well-known framework outlined by Schegloff et al. (1977) suggested 4 main ways that this repair function can be performed: 1) self-initiated self-correction; 2) self-initiated other-correction; 3) other-initiated selfcorrection; and 4) other-initiated other-correction. In the classroom, types 3 and 4 are far more frequent (McHoul, 1990). The context offers insight into the reported frequency of types 3 and 4; namely a classroom is a learning environment, and the knowledge and power within it is asymmetrical. The adult instructor has the knowledge and asks most of the questions with the objective being to teach the pupils. It is therefore the pupils who make the most errors, so other-initiation (from the teachers) often leads to self-correction by the pupils, or (less often) other correction by the teacher (McHoul, 1990; Radford, Blatchford, \& Webster,2011). So, follow-up strategies are an extremely important, if not vital, element of classroom discourse 
making them an important linguistic strategy to examine in relation to gender.

\section{Methodology}

Fieldwork was conducted in 4 co-educational primary schools in Hertfordshire, U.K sampled on basis of teacher gender resulting in a total of 12 teacher participants, 6 men and 6 women. All teachers were white and British. This is not a representative sample of gender, class or race, and cannot provide insights into intersectionality, but was ample for a qualitative, exploratory case study and provided a substantial database of classroom interaction. The data was collected by the author and consists of 2 full school days of both video and audio recordings per teacher, resulting in approximately 120 hours of classroom discourse which were transcribed and then coded using NVivo 11 plus. Video recordings were employed for transcription purposes (e.g. allowing to identify the pupils within group discussions and teacher- fronted whole-class lessons) and for the examination of nonlinguistic behaviour (e.g. body language). Ethical approval was firstly applied for and granted from the University of Hertfordshire. To obtain access to schools, the author first contacted headteachers which led to a meeting with the teachers within these schools to explain the study. After Headteacher and teacher consent was given, information sheets and consent forms were sent out to the parents to sign and return (opt-in consent). Only two parents across the study declined their child to take part. On the days of recording, these two children went into another class for the day.

The main analyses were conducted by the author on teacher-to-pupil talk during all-class instruction. To make the pedagogical field similar, this paper focuses on English and Mathematics lessons across all sets of data. The discursive analytical approach taken was Interactional Sociolinguistics (IS), a multidisciplinary paradigm which allowed a fine-grained examination of the data whilst acknowledging the importance of conversational context. Butler's (1990) view of gender as a performed social construct and not a fixed inherent category (social constructionism) has had an impact on language and gender research, encouraging a move away from essentialist perceptions that language is innately linked to gender, to focusing on what we do to actively enact our identity in relation the context in which we are situated. Therefore, data analysis is situated in the IS paradigm, which embraces the social-constructionist views of gender to address the possible contextual causes behind speakers' discursive behaviours (Holmes, 2006).

Data was analysed using linguistic frameworks complied from previous sociolinguistic research. These included Brown and Levinson's (1987) politeness model; Coates' (1996) taxonomy on collaboration and mitigation, and Holmes' $(1982,1990,1995)$ frameworks on tag questions, hedging and politeness. These frameworks were chosen as they are well established and frequently used within Interactional Sociolinguistics to categorize linguistic features and their functions. Comparative analysis across all data allowed the identification of patterns of differences and similarities, and empirical findings were drawn together into an overall analysis. For an initial identification of instances of the type of follow up move employed, a taxonomy was created using several existing frameworks (outlined below). To warrant data analysis and interpretation, the data was discussed with other prominent researchers in this area of study and results presented at both linguistic and education conferences. Furthermore, four workshops with practitioners were held and over 50 extracts discussed, the analysis of which was very well received and agreed upon (Holmes, 2014).

\section{What is the 'Follow-Up' Move? Creating a Framework for Analysis.}

There are many different frameworks that attempt to classify the various types of F-moves; most of which have only been used within one pedagogical area (e.gs Mathematics, Languages). The most productive forms of follow-up come in the form of other-initiated, selfrepair strategies as they foster student independent thinking and learning. These include prompts and questions, where the follow-up aids the pupil to reach the correct answer (Radford et al. 2011). This type of follow-up can also come in the form of a repeat and a hint, where the repetition of the question can aid the student to focus attention on the error. Otherinitiated, other-repair strategies (where the teacher simply provides the correct answer right away) are used to aid on-task behaviour and focus on task completion, so do not explore students' awareness or grasp of the topic, nor allow them to develop any topic understanding.

As data is considered from an interactive angle, it is also important to analyse the pupil's 
response using Chin's (2006) coding of correct; mixture of correct and incorrect (or incomplete) and incorrect responses. The framework, distinguishes between 4 types of follow-upbased on how 'incorrect' the pupil's response was. In instances where the student gave an incorrect answer, teachers either gave an 'Explicit Correction-Direct instruction' or 'Constructive Challenge'. The explicit correction was followed by an explanation of the topic, whereas a constructive challenge existed of an evaluation or neutral remark on the answer and a reformulation of the question. In response to a combination of a correct and incorrect answer, teachers gave follow-up that included an acceptance of the response and subsequent follow up questions to elicit the correct answer to encourage students to think more in depth. This was labelled as 'Extension by responsive questioning: Focusing and Zooming'. Correct student responses were given follow-up labelled 'Affirmation-Direct instruction' (Chin, 2006: 1326) where teachers usually confirmed the answer was correct through reinforcement (i.e. repetition of answer in some form) elaborating on the response, and then giving further direct instruction.

Lyster (1998) highlights 6 main types of follow-up used by teachers which are explicit correction; recasts; elicitation; metalinguistic cues; clarification requests and repetition. While Vehkakoski (2010) further classifies follow-up as; positive evaluative follow-up (student gets answer correct); and negative or corrective follow-up (student gets answer wrong or partly wrong).Negative/corrective follow-up can be further broken down into several categories where the teacher encourages learner to self-repair (via recasts, prompts, expansions; cues; clarification requests) or performs other-repair (replacing errors by explicitly correcting expressions; giving the correct answer). Ellis et al.(2006) have argued that different types of corrective follow-up fall along a continuum between implicit and explicit follow-up. Recasts and reformulations lean towards a more implicit end while explicit forms are usually in the form of negotiations such as confirmation checks and clarification requests that require students to elicit the correct utterance.

This paper adopts the term 'follow up' and is interested in the varied and wide range of follow up responses discussed in this section that can be utilised by the teacher. However, teachers must also be aware of the power imbalance and the potentially damaging effect of any followup strategies on the pupil. Therefore, it is also of interest to examine what linguistic strategies the teachers implement to counteract these negative effects. Investigating the linguistic style employed by the teachers when delivering oral feedback (see table 1) as well as the type of follow-up strategies used, will reveal how feedback is linguistically delivered to explore whether teacher gender makes any difference to teaching style, as well as generating new insights on how follow-up strategies are delivered within the primary school classroom by male and female teachers.

\section{Results}

The extracts presented in section 4.1 present insights from the qualitative data analysis. They demonstrate a mix of male and female teachers teaching in the pedagogical fields of English and Maths. As no differences were evident between a)teaching styles and b) across pedagogical fields, the extracts selected for this paper have been chosen as they are representative of the follow-up strategies commonly used by the teachers in this study. These are the positive, productive, type of follow up; other-initiated self-repair where the teachers get the student to correct their own response rather than give the answer directly (which is the more face threatening, other-initiated, other-repair). As to be expected, these strategies are not always successful in eliciting the correct answer from the pupil straightaway, so it is interesting to observe what the teachers did next in such cases. Rather than simply providing the correct answers, teachers continued to provoke pupil(s) self-repair, often achieved via the use of hints, prompts, questions (elicitation), recasts and repetition (Ellis et al, 2006; Lyster, 1998; Vehkakoski, 2010). Therefore, all teachers regardless of gender, are repeatedly attempting to elicit correct answers via self-repair to foster the independent thinking that is gained when pupilsreach the answer themselves.

\section{Teachers' Follow-Up Strategies: Eliciting Self-Repair}

In extract 1, Val is teaching her Year 5's Mathematics using number bonds. In line 1, she initiates the IRF sequence by asking her female pupil Katie to give the answer supported by her "working out". This allows the teacher to assess the pupil's understanding of the topic, as well as demonstrate to the class how to work out the correct answer. In line 4-5, Katie's 
response is incomplete (more a repetition of the question) as she does not explain how she knows the numbers are the same, as requested to do by Val's initiation. So, Val prompts for the correct answer by repeating the initial question, recasting Katie's contribution which implicitly shows an error has been made, which the pupil then self-repairs (Ellis et al. 2006). Val then offers implicit confirmation by affirming the answer is correct through repetition of both Katie's responses in lines 10-13. This is followed by direct explanation "so it's exactly the same as that"and further instruction which acts as an initiation turn in line 14 (Chin, 2006; Sinclair \& Coulthard 1975). Val's follow-up in line 17 is an explicit affirmation "yes"accompanied with an explanation:

Extract 1. Val teaching Maths to Year 5 pupils

\begin{tabular}{|c|c|c|c|}
\hline Line No. & Speaker & Utterance & $\begin{array}{l}\text { Response and Follow-up } \\
\text { strategy }\end{array}$ \\
\hline $\begin{array}{l}1 \\
2 \\
3\end{array}$ & Val & $\begin{array}{l}\text { Prove to me why they are exactly the same, you have to back } \\
\text { up your answer. Go ahead } \\
\text { Val }\end{array}$ & Initiation \\
\hline $\begin{array}{l}4 \\
5\end{array}$ & Katie & $\begin{array}{l}\text { They are the same numbers but erm that one's } \\
\text { just partitioned }\end{array}$ & Response (not complete) \\
\hline $\begin{array}{l}6 \\
7\end{array}$ & Val & $\begin{array}{l}\text { How do you know that they're the same numbers? to same } \\
\text { student\} }\end{array}$ & $\begin{array}{l}\text { Follow-up: extension by } \\
\text { responsive question; } \\
\text { prompts }\end{array}$ \\
\hline $\begin{array}{l}8 \\
9\end{array}$ & Katie & $\begin{array}{l}\text { Because forty add nine is forty-nine and twenty add four is } \\
\text { twenty-four }\end{array}$ & Response (correct) \\
\hline $\begin{array}{l}10 \\
11 \\
12 \\
13 \\
14 \\
15\end{array}$ & Val & $\begin{array}{l}\text { So they're just partitioned so if you did the actual sum forty } \\
\text { add nine is forty-nine twenty add four is twenty-four. } \\
\text { So it's exactly the same as that. } \\
\text { So will they both give you the same } \\
\text { answer? }\end{array}$ & $\begin{array}{l}\text { Follow up: evaluative } \\
\text { implicit; affirmation - } \\
\text { direct- instruction } \\
\text { Initiation }\end{array}$ \\
\hline 16 & Katie & Yes & Response (correct) \\
\hline 17 & Val & Yes because they are exactly the same & $\begin{array}{l}\text { Follow up: explicit } \\
\text { affirmation-direct- } \\
\text { instruction; explanation }\end{array}$ \\
\hline
\end{tabular}

In extract 2, Val is teaching her class English. Her pupil, Michaela, provides an incorrect answer in line 2 which Vale valuates with a follow up containing the negative response "no" to explicitly indicate pupil error before prompting for the correct answer with a question (Lyster, 1998; Vehkakoski,2010). But to mitigate the threatening act of telling Michaela that she got the answer incorrect (Brown \& Levinson 1987), Val reformulates part of the pupil's response to show that speech marks do indeed play some role at some stage (Ellis et al., 2006; Holmes \& Stubbe, 2015). Val then remains with Michaela to prompt for the correct answer. She withholds the correct answer to achieve other initiated self-repair by re-asking the question in the form of a constructive challenge (Chin, 2006). In line 6, Michaela eventually gets the correct answer, to which Val follows up with implicit positive evaluation via the exact repetition of the pupil's answer 'a comma', accompanied with further instruction and direction (Chin, 2006; Vehkakoski, 2010): 
Extract 2.Val teaching English

\begin{tabular}{|c|c|c|c|}
\hline $\begin{array}{l}\text { Line } \\
\text { No. }\end{array}$ & Speaker & Utterance & $\begin{array}{l}\text { Response and } \\
\text { Follow-up strategy }\end{array}$ \\
\hline 1 & Val & What kind of punctuation Michaela & Initiation \\
\hline 2 & Michaela & Erm speech marks? & Response: incorrect \\
\hline $\begin{array}{l}3 \\
4 \\
5\end{array}$ & Val & $\begin{array}{l}\text { No, we are closing with speech marks } \\
\text { but before we do that what are we } \\
\text { putting? }\end{array}$ & $\begin{array}{l}\text { Follow-up: Explicit } \\
\text { evaluation and } \\
\text { reformulation of } \\
\text { student utterance; } \\
\text { constructive } \\
\text { challenge }\end{array}$ \\
\hline 6 & Michaela & A comma & Response: correct \\
\hline $\begin{array}{l}7 \\
8 \\
9 \\
10 \\
11 \\
12 \\
13 \\
14\end{array}$ & Val & $\begin{array}{l}\text { A comma. We've got to have punctuation when } \\
\text { we close the speech marks whether it be a full } \\
\text { stop, comma, exclamation mark, question mark, } \\
\text { but more importantly, is the way that somebody } \\
\text { says something \{clears throat\} there's lots of } \\
\text { ways to say something isn't there? Okay, lots of } \\
\text { different feeling involved when you say } \\
\text { something, okay. }\end{array}$ & $\begin{array}{l}\text { Follow-up: } \\
\text { Affirmation- direct- } \\
\text { instruction; } \\
\text { evaluative comment } \\
\text { via repeating } \\
\text { student's } \\
\text { contribution. }\end{array}$ \\
\hline
\end{tabular}

Similar strategies are employed by the teacher Phil when teaching Mathematics to his Year 5 class in extract 3 below:

Extract 3.Phil teaching Mathematics

\begin{tabular}{|c|c|c|c|}
\hline $\begin{array}{l}\text { Line } \\
\text { No. }\end{array}$ & Speaker & Utterance & $\begin{array}{l}\text { Response and Follow- } \\
\text { up strategy }\end{array}$ \\
\hline $\begin{array}{l}1 \\
2\end{array}$ & Phil & $\begin{array}{l}\text { Okay how much are we taking away? \{Boy } \\
\text { puts his hand up\} Michael? }\end{array}$ & Initiation \\
\hline 3 & Michael & Sixty grams & Response (incorrect) \\
\hline 4 & Phil & Sixty grams. Just sixty grams? & $\begin{array}{l}\text { Follow-up: Evaluative } \\
\text { via repetition of } \\
\text { student's contribution; } \\
\text { Implicit prompt using } \\
\text { repetition; constructive } \\
\text { challenge }\end{array}$ \\
\hline 5 & Michael & Erm... & No response \\
\hline $\begin{array}{l}6 \\
7 \\
8\end{array}$ & Phil & $\begin{array}{l}\text { There's a really important bit here }\{\text { Teacher } \\
\text { underlines bits on the board\}. Mr. Michael can } \\
\text { you read all the bits underlined in green }\end{array}$ & $\begin{array}{l}\text { Follow up: } \\
\text { Constructive challenge; } \\
\text { prompt; hint }\end{array}$ \\
\hline 9 & Michael & Erm, each week? & Response: correct \\
\hline $\begin{array}{l}10 \\
11\end{array}$ & Phil & $\begin{array}{l}\text { Each week. Sixty grams each week he loses } \\
\text { sixty grams each week. Read the last bit }\end{array}$ & $\begin{array}{l}\text { Follow-up: } \\
\text { implicit affirmation via } \\
\text { repetition of student's } \\
\text { contribution; } \\
\text { affirmation -direct- } \\
\text { instruction }\end{array}$ \\
\hline
\end{tabular}

In line 1, Phil initiates the sequence by asking a question to the entire class. Michael raises his hand so is rewarded by being allowed to give his answer, which is incorrect (line 3). Phil remains with this pupil and indicates in his follow up response that "sixty grams" is incorrect. This is performed indirectly via a direct repetition of the pupil's answer which is then further repeated with rising intonation to implicitly indicate error and create a constructive challenge (Chin, 2006; Ellis et al. 2006; Lyster 1998). Michael does not offer a response in line 5, so is further prompted by Phil in his follow up in lines 6-8 where he offers Michael a hint to draw attention to the important information needed to solve the problem, "read all the bits underlined in green" to create a constructive challenge. This works as it aids Michael to get the correct answer (line 9), to which Phil responds with implicit affirmation via repetition of the pupil's contribution (Vehkakoski 2010), which he then expands with direct instruction (Chin, 2006) to move on the next initiation sequence. This strategy of remaining with the same pupil to probe them repeatedly until they arrive at the correct answer (as seen in extracts 1-3) has been described as a 'masculine' teaching style as it continually challenges the same student 
which can cause distress and embarrassment. In fact, it is a style that is stereotyped to be used only by male teachers (Good, Sikes \& Brophy 1973). However, both male and female teachers employed this strategy when teaching.

In Extract 4, Lucy is teaching English to her Year 6 class. As in the other extracts, Lucy frequently use constructive challenges, hints and prompts to get pupils to self-repair:

Extract 4.Lucy teaching English

\begin{tabular}{|c|c|c|c|}
\hline $\begin{array}{l}\text { Line } \\
\text { No. }\end{array}$ & Speaker & Utterance & $\begin{array}{l}\text { Response and Follow- } \\
\text { up strategy }\end{array}$ \\
\hline $\begin{array}{l}1 \\
2\end{array}$ & Lucy & $\begin{array}{l}\text { What is a pronoun, can anybody tell me what } \\
\text { a pronoun is? \{most raise hands\} Catlin? }\end{array}$ & Initiation \\
\hline $\begin{array}{l}3 \\
4\end{array}$ & Catlin & $\begin{array}{l}\text { Erm is a is a pronoun something that's it's } \\
\text { it's a proper noun like (.) like a name }\end{array}$ & Response: incorrect \\
\hline $\begin{array}{l}5 \\
6 \\
7 \\
8\end{array}$ & Lucy & $\begin{array}{l}\text { (To class) Did you notice that Catlin found } \\
\text { another word in there, there was a prefix and } \\
\text { a word, what word did Catlin add in to find } \\
\text { that? Ruth? }\end{array}$ & $\begin{array}{l}\text { Follow-up: implicit } \\
\text { evaluation; constructive } \\
\text { challenge opened to } \\
\text { class indicates error; } \\
\text { hints and prompts; } \\
\text { recasts answer to create } \\
\text { new initiation to class }\end{array}$ \\
\hline 9 & Ruth & a noun & Response: Correct \\
\hline $\begin{array}{l}10 \\
11 \\
12\end{array}$ & Lucy & $\begin{array}{l}\text { She found the word noun. Alright so } \\
\text { pronoun, it's got something to do with a } \\
\text { noun. What is a noun? }\end{array}$ & $\begin{array}{l}\text { Follow-up: Evaluative } \\
\text { implicit affirmation via } \\
\text { repetition; affirmation - } \\
\text { direct- instruction; hints } \\
\text { and prompts to } \\
\text { reinitiate question to } \\
\text { whole class }\end{array}$ \\
\hline
\end{tabular}

Lucy initiates the sequence in line 1 to the entire class and then she passes the turn to Catlin, who has her hand raised in response to the question. Unfortunately, she gets the answer incorrect. Rather than answer Catlin directly, Lucy explicitly evaluates her response to the whole class "did you notice that Catlin found another word in there" in lines 5-6 (Ellis et al.,2006). With-holding the correct answer, Lucy asks another question to the whole class recasting Catlin's response to form hints and prompts to create a new question in lines 5-7, encouraging the entire class to self-repair (Lyster, 1998). Ruth responds by raising her hand so is chosen to deliver the answer which she gets correct. Lucy's follow-up in line 10 indicates Ruth's answer is correct via implicit affirmation achieved through repetition of the pupil's contribution, followed by a direct comment and further instruction (Chin 2006). She uses further hints and prompts to reinitiate the question once again to the whole class. It appears that Lucy is attempting to work backward to gain the correct answer to her first question in line 1. If the pupils can identify a noun, they can work toward the definition of a pronoun to enhance their understanding of the topic. This strategy of opening the question up to the whole floor to achieve repair rather than remaining with the pupil who got the answer incorrect was a common strategy in the data. In relation to the stereotypical gendered speech styles (see table 1 ), this could be described as a 'feminine' style, where the teacher does not continue to probe the same student which can cause embarrassment and demotivation, but instead allows the teacher to protect the pupil's face (Holmes \& Stubbe 2015). However, it was a technique employed commonly by both male and female teachers (see extracts 4-7).

Ben is teaching English to his Year 5 class in extract 5. He initiates the topic using a question that is open to the entire class and chooses Sally who has her hand raised. Sally responds with the correct answer in line 4. Ben follows up with implicit positive evaluation through repetition, and then gives explicit praise "well-done" (Vehkakoski 2010). This is followed by another initiation open to the entire class and this time Ben chooses Hannah to answer, who gives the incorrect response "three". In line 10, Ben explicitly evaluates Hannah's answer using the negative 'not' before repeating her incorrect attempt "three lines". This negative corrective feedback with holds the correct answer to act as a prompt to encourage other students to repair, and this is evidenced by a batch of students raising their hands (Vehkakoski 2010). The correct answer is provided by another pupil Mark in line 12 which is affirmed and implicitly 
evaluated via direct repetition and praise. This is followed by direct instruction (Chin, 2006) and Ben signals the move to the next part of the lesson via the discourse marker 'okay' (Sinclair \& Coulthard, 1975).

\section{Extract 5.Ben teaching English}

\begin{tabular}{|l|l|l|l|}
\hline $\begin{array}{l}\text { Line } \\
\text { No. }\end{array}$ & Speaker & Utterance & $\begin{array}{l}\text { Response and Follow- } \\
\text { up strategy }\end{array}$ \\
\hline 1 & Ben & $\begin{array}{l}\text { Who can remember what a haiku is? \{Some } \\
\text { children raise their hands\} } \\
\text { Sally? }\end{array}$ & Initiation \\
3 & & $\begin{array}{l}\text { Erm basically a poem with seventeen } \\
\text { syllables }\end{array}$ & Response: correct \\
\hline 4 & Sally & $\begin{array}{l}\text { With seventeen syllables well done. How is it } \\
\text { structured. How many lines are there? }\{\text { Some } \\
\text { children raise their hands\} Hannah? }\end{array}$ & $\begin{array}{l}\text { Follow up: evaluation } \\
\text { via repetition; praise; } \\
\text { affirmation-direct- } \\
\text { instruction; initiation }\end{array}$ \\
\hline 6 & Ben & & Response: incorrect \\
8 & & Three & $\begin{array}{l}\text { Follow-up: explicit } \\
\text { evaluation repetition of } \\
\text { student's answer after } \\
\text { negative 'not' }\end{array}$ \\
\hline 9 & Hannah \\
10 & Ben & Not three lines $\{$ Teacher selects another & Response: correct \\
\hline 12 & Mark & Four & $\begin{array}{l}\text { Follow-up: implicit } \\
\text { evaluation via } \\
\text { repetition and praise }\end{array}$ \\
\hline 13 & Ben & Four lines well done, okay &
\end{tabular}

In extract 6, there is further evidence of the technique of opening the floor to the whole class when a student has got an answer incorrect:

Extract 6.Tim teaching English

\begin{tabular}{|c|c|c|c|}
\hline $\begin{array}{l}\text { Line } \\
\text { No. }\end{array}$ & Speaker & Utterance & $\begin{array}{l}\text { Response and Follow- } \\
\text { up strategy }\end{array}$ \\
\hline 1 & Mark & As fast as like lightning speed & $\begin{array}{l}\text { Response: } \text { mix of } \\
\text { incorrect and correct }\end{array}$ \\
\hline $\begin{array}{l}2 \\
3 \\
4 \\
5 \\
6\end{array}$ & Tim & $\begin{array}{l}\text { As fast as the speed of lightning yeah not as } \\
\text { fast why would you not why would you never } \\
\text { say as fast like? \{addresses whole class\} why } \\
\text { would you never say as fast as like? \{Some } \\
\text { children raise their hand yeah? }\end{array}$ & $\begin{array}{l}\text { Follow up: } \\
\text { reformulation of } \\
\text { student's contribution; } \\
\text { reinitiates to entire } \\
\text { class using constructive } \\
\text { challenge; prompts }\end{array}$ \\
\hline $\begin{array}{l}7 \\
8\end{array}$ & Mark & $\begin{array}{l}\text { Because like basically you haven't used two } \\
\text { words that mean a simile }\end{array}$ & $\begin{array}{l}\text { Response: mixture of } \\
\text { correct and incorrect }\end{array}$ \\
\hline $\begin{array}{l}9 \\
10\end{array}$ & Tim & $\begin{array}{l}\text { Well done very good you either have as and as } \\
\text { or you have like on its own }\end{array}$ & $\begin{array}{l}\text { Follow up- evaluative } \\
\text { affirmation using } \\
\text { praise; reformulation of } \\
\text { student's contribution }\end{array}$ \\
\hline
\end{tabular}

Here Tim reformulates Mark's partially incorrect answer to produce it correct syntactically (line 2). Although he is providing some form of correction by reformulating Mark's partly correct response (and therefore implicitly telling Mark he is incorrect [Ellis et al., 2006]) Tim uses this as an opportunity to form a constructive challenged by asking the whole class why "like" is not part of the simile (Chin, 2006). This reformulation encourages students to rectify the mistake made in the previous response without directly damaging the pupil's face (Holmes \& Stubbe, 2015). As Mark was partially correct, Tim leads with the positive (that Tim was nearly there with his answer) rather than say Mark was incorrect. This reformulation is then supplemented with the use of prompts as a facilitative device to encourage the whole class to participate and provide the correct response (Lyster, 1998). Mark has another attempt, and this time his answer is mainly correct, but is still a little muddled. Therefore, Tim offers positive evaluative feedback, providing implicit affirmation using praise "well done, very good"and once again reformulates Mark's contribution to make sure the other students are all clear and understand 
the concept (Vehkakoski, 2010).

In extract 7, Don is teaching Maths to Year 6 pupils, and again we see the mitigating strategy of using a constructive challenge to reinitiate the question to the group, not the pupil (Chin, 2006). Kate, the pupil, gives a partially correct and incorrect answer, so Don moves on and follows up with a constructive challenge by asking the class to repair with a prompt in line 3 followed by the hint that "Kate's got the right answer-ish" (line 4). This hint also acts as a mitigating strategy as it reduces the level of error made by the student; her answer was very close to being correct, but just needs a 'tweak':

Extract 7.Don Teaching Maths

\begin{tabular}{|l|l|l|l|}
\hline $\begin{array}{l}\text { Line } \\
\text { No. }\end{array}$ & Speaker & Utterance & $\begin{array}{l}\text { Response and Follow- } \\
\text { up strategy }\end{array}$ \\
\hline 1 & Don & $\begin{array}{l}\text { Erm question nine what's the new product } \\
\text { Kate }\end{array}$ & Initiation \\
\hline 2 & Kate & Erm its two numbers & $\begin{array}{l}\text { Response: mix of } \\
\text { correct and incorrect }\end{array}$ \\
\hline 3 & Don & $\begin{array}{l}\text { Well now who can tell me what the product } \\
\text { actually means, and Kate's got the right } \\
\text { answer-ish let's just tweak it } \text { students raise } \\
\text { hands } \text { Eddie? }\end{array}$ & $\begin{array}{l}\text { Follow up: contrastive } \\
\text { challenge; prompts a } \\
\text { repair by moving on } \\
\text { and opening to class; } \\
\text { reinitiates }\end{array}$ \\
\hline 7 & Eddie & $\begin{array}{l}\text { Erm product means what two numbers } \\
\text { multiply together to get the new number }\end{array}$ & $\begin{array}{l}\text { Response: correct } \\
8\end{array}$ \\
\hline
\end{tabular}

This deployment of mitigation is a face-saving strategy that allows the teacher to reduce the level of criticism and therefore embarrassment of getting an incorrect answer, which is important for student motivation and participation (Brown \& Levinson, 1987, Cullen, 2002).Being critiqued openly in class may be enough to prevent a pupil from choosing to answer any questions again.

\section{Conclusion}

This study has demonstrated both female and male teachers making heavy use of otherinitiated self-repair strategies in their lessons when pupils gave an incorrect/partially incorrect answer. A recurrent follow-up method was the constructive challenge, consisting of an evaluation or neutral comment on the pupil's answer and then the teacher's initial elicitation being reformulated by means of an alternative question (Chin, 2006). This strategy encouraged students to rectify the mistake made in the previous response. In response to a combination of a correct and incorrect answer, teachers often gave feedback that included an acceptance of the response and subsequent follow up questions to elicit the correct answer to encourage students to think more in depth. This is a mitigated, indirect strategy, which takes into consideration the damaging effect that corrective follow-ups may cause and therefore were used to protect the pupil's face (Brown \& Levinson, 1987; Holmes \& Stubbe, 2015). Furthermore, the use of prompts and hints were often employed as a both a softening and a facilitative device to encourage the pupils to participate and provide the correct response (Lyster 1998; Rubie-Davies, Blatchford, Webster, Koutsoubou \& Bassett, 2010). This linguistic style, that was adopted by all teachers regardless of their gender, is one that is frequently indexed as normatively feminine. The use of such linguistic strategies serve to mitigate the force of the follow up when students provide incorrect/partially correct answers, as well as support students' thinking and working together to solve a problem as a team (Fletcher, 2018; Holmes \& Stubbe, 2015). This suggests that such strategies are key in working against any negative effects of direct, corrective other-repair, to promote a supportive learning environment and encourage learners to participate (Cullen, 2002).However, direct, unmitigated styles that have been described as 'typically masculine' in gendered discourse (Holmes, 2006) were also visible as part of every teachers' repertoire. This was evident when teachers probed the same pupil for a correct response after they got an answer wrong, rather than moving onto another pupil. This could be potentially face-threatening and embarrassing for the pupil (Brown \& Levinson, 1987; Cullen, 2002; Ridley, Radford \& Mahon, 2002).

Also evident in both male and female teachers' use of follow-up was the use of both implicit 
and explicit feedback. Teachers employed recasts, reformulations and repetition, which are more implicit forms of corrective feedback, as well as elicitations and confirmation checks which are more explicit, direct follow-up forms (Ellis et al., 2016). The use of implicit evaluation was often mitigated further with a positive comment accompaniment (i.e. identifying something close/similar/relevant in the incorrect answer). The implicit strategy of verbatim repetition was a key strategy in the teachers' style when students got answer both incorrect and correct. What mainly separated the two was the use of praise when students got an answer correct; and the deployment of rising intonation when the answer was incorrect. Incorrect answers were often repeated by the teacher using rising intonation to present them as a re-initiation to indicate an error and encourage students to self-repair (Ridley et al., 2002).

Arguably then, teachers utilised a mixture of linguistic strategies indexed for masculinity and femininity for comparable purposes. From this analysis, this study suggests that teacher 'gender' does not affect the choice of follow-up strategies used, nor the linguistic style employed to perform it. Instead what seems to be important is the accuracy of the student response, and how the teacher deals with each pupil as an individual learner. Teachers need to constantly adapt and style shift, employing strategies that are best suited to each individual pupil. Women and men have a wide range of communicative skills in their linguistic arsenal, so as competent teachers they need to use whichever style (both 'feminine' and 'masculine' indexed norms) that is required to perform their teaching role. Therefore, each teacher's linguistic performance could be to some extent determined by their mutual workplace culture, with the linguistic repertoire of their setting having some form of influence on their linguistic choices (Marra, Schnurr \& Holmes, 2006; Powell, Bagilhole \& Dainty, 2009). Evidence of adapting one's language to the surrounding context has been found in many linguistic studies of the workplace (Holmes, 2006; King, 2018; McDowell, 2018), meaning we perform our identities differently according to the context in which we currently find ourselves.

The issue is that women make up over 85 percent of primary school teaching in the U.K., and this is partially to do with the prevailing assumption that they have the necessary communication skills to perform the job simply due to their gender (Hultgren, 2017; Litosseliti \& Leadbeater, 2013). Our gendered stereotypes of what this role entails, and the characteristics assumed necessary to adequately perform it, can only contribute to the continued lack of men in these occupations. Men often decide against becoming a primary teacher because they think it is a female profession (Warwick, Warwick \& Hopper, 2012). Destereotyping the role is of key importance as we need more qualified teachers in the U.K. We need to argue that the speech style of performing this role is not linked to gender, but more relevant to the environment in which they are working. Teachers are orienting to the community in which they belong (King, 2018; Wenger, 1998); that of being a primary school teacher, and competent, effective ones at that. It is therefore important to re-interpret language use as reflecting professional identity rather than gender identity. This research may also have important implications for government incentives, which should consider advertising the wide range of skills needed to be a teacher, and not just attempt to recruit men by trying to make the role more hegemonically 'masculine', which can act as a deterrent to some men. By shedding light on how language is used in the classroom, this study has produced valuable insights on how men and women actually use language to perform their professional identity (Clark, 2018; Hultgren, 2017; McDowell \& Klattenberg, 2018; Mullany \& Yoong, 2018). This study has demonstrated both male and female teachers actively constructing a context dependent teaching identity, with their language breaking stereotypical gendered norms of speaking. The discursive behaviour of these teachers should therefore not be described as 'masculine' or 'feminine', but rather labelled as the discourse of doing 'being' a teacher if we are ever to move away from persistent gendered stereotypes.

Despite the investigation of occupational language being a growing area in workplace studies, more research is needed into linguistic behaviour in 'non-traditional' jobs. This study begins to address this gap and contributes to studies of workplace discourse by lending support to existing arguments that gender is not the only influencing variable on speech. The linguistic strategies in the data allows them to perform discourse tasks essential to their profession supporting current arguments that linguistic forms are not exclusive to one gender or the other (Schnurr, 2013; Mullany, 2014). The description of the language in this paper is not representative of all male and female teaching behaviour across the U.K. (see McDowell \& Klattenberg, 2018). To explore this, further research in this area would involve additional data 
collection from a larger number of male and female teachers across more primary schools within the U.K to investigate if these current paper's findings are replicated, and allow intersectionality to also be considered.

\section{Acknowledgements}

I would like to express my thanks to all the teachers and pupils who participated in this study, and to all my peers who reviewed this paper.

\section{Funding}

This research received no specific grant from any funding agency in the public, commercial, or not-for-profit sectors.

\section{Declaration of conflicting interests}

The author declared no potential conflicts of interests with respect to the authorship and/or publication of this article.

\section{References}

Allan, J. (1993). Male elementary teachers: Experiences and perspectives. In Doing 'women's work': Men in non-traditional occupations, edited by Christine. L. Williams. California: Sage.

Ankers de Salis, C., Rowley, A., Stokell, K., \& Brundrett, M. (2018). Do we need more male primary teachers? Tensions and contradictions in the perspectives of male and female trainees. Education, 3-13 DOI: $10.1080 / 03004279.2018 .1498997$

Angouri, J. (2011). We are in a masculine profession ...: Constructing gender identities in a consortium of two multinational engineering companies. Gender and Language, 5, 373-404.

Bhana, D., \& Moosa, S. (2016). Failing to attract males in foundation phase teaching: An issue of masculinities. Gender and Education http://dx.doi.org/10.1080/09540253.2015.1105934

Bradley, H. (1993).Across the great divide: The entry of men into women's jobs. In Doing women's work: Men in non-traditional occupations, edited by Christine. L. Williams. California: Sage.

Britton, Dana. (2000). The epistemology of the gendered organization. Gender and Society, 14:418-34.

Brown, P., \& Levinson, C. S. (1987). Politeness: Some universals in language usage. Cambridge: Cambridge University Press.

Brundrett, M, Ankers De Salis, C, Rowley, A ,\& Stokell, K (2018) Do we need more male primary teachers? Tensions and contradictions in the perspectives of male and female trainees. Education 3-13: International Journal of Primary, Elementary and Early Years Education. ISSN 1475-7575.

Bullough, R. (2015).Differences? Similarities? Male teacher, female teacher: An instrumental case study of teaching in a head start classroom. Teacher and Teacher Education, 47, 13-21.

Burke, S., \& Collins, K. (2001).Gender differences in leadership styles and management skills. Women in Management Review, 16, 244-256.

Buschor, C. B., Kappler, C., Frei, A. K., \& Berweger, S. (2014). I want to be a scientist/a teacher: Students' perceptions of career decision making in gender-typed, non-traditional areas of work. Gender and Education, 26, 743-758.

Butler, J. (1990). Gender Trouble: Feminism and the Subversion of Identity. London: Routledge.

Cameron, D. (2007). The myth of Mars and Venus: Do men and women really speak different languages? Oxford: Blackwell.

Carli, L., Alawa, L., Lee, Y., Zhao, B., \& Kim, E. (2016). Stereotypes about gender and science: Women scientists. Psychology of Women Quarterly,40, 244-260.

Carrington, B., Francis, B., Hutchings, M., Skelton, C., Read, B., \&Hall, I. (2007). Does the gender of the teacher really matter? Seven to eight-year-olds' accounts of their interactions with their teachers. Educational Studies, 33, 397-413.

Carrington, B., Tymms, P., \& Merrell, C. (2008). Role models, school improvement and the 'gender gap'-do men bring out the best in boys and women the best in girls? British Educational Research Journal,34, 
315-327.

Chin, C. (2006). Classroom interaction in science: Teacher questioning and feedback to students' responses. International Journal of Science Education ,28, 1315-1346.

Clark, B. (2018). Professional identity construction: Cabin crew discourse. In The Routledge handbook of workplace discourse, edited by Bernadette Vine. Routledge: London.

Coates, J. (1996). Women talk: Conversation between women friends. Oxford: Blackwell.

Cruickshank, V., Pedersen, S., Cooley, D., \& Hill, A. (2018).Towards a measure of gender-related challenges faced by male primary teachers. Australian Journal of Education, 0, 1-12.

Cullen, R. (2002). Supportive teacher talk: The importance of the F-move. ELT Journal, 56, 117-127.

Department of Education.(2016). School Workforce in England. November 2015. Retrieved from:https://www.gov.uk/government/uploads/system/uploads/attachment_data/file/533618/SFR21_2016 _MainText.pdf [accessed August 2017]

Didham, R. (2015). Re-gendering of the workforce: Women and men in non-traditional occupations and industries. Labour, Employment and Work in New Zealand [S.I].

Eckert, P., \& McConnell-Ginet, S. (1999). New generalisations and explanations in language and gender research. Language in Society, 28, 185-201.

Eckert, P., \& McConnell-Ginet, S. (2003). Language and gender. Cambridge: Cambridge University Press.

Ellis, R, Loewen, S., \& Erlam, R. (2006).Implicit and explicit corrective feedback and the acquisition of L2 grammar. Studies in Second Language Acquisition, 28(2), 339-368.

Fletcher, J. (2018). Rapport Management. In The Routledge handbook of workplace discourse, edited by Bernadette Vine. Routledge: London.

Good, T., Sikes, S., \& Brophy, J. (1973). Effects of teacher sex and student sex on classroom interaction. Journal of Educational Psychology, 65, 74-87.

Haines, E., Deaux, K., \& Lofaro, N. (2016).The times they are a- changing or are they not? a comparison of gender stereotypes, 1983-2014. Psychology of Women Quarterly,40, 353-363.

Holmes, J. (1982). Functions of tag questions. English Language Research Journal, 3, 40-65.

Holmes, J. (1990). Hedges and boosters in women's and men's speech. Language and Communication, 10, 185-205.

Holmes, J. (1995). Women, men, and politeness. London: Longman.

Holmes, J. (2006). Gendered talk at work. Constructing social identity through work place interaction. Oxford: Blackwell Publishing.

Holmes, J. (2014). Doing discourse analysis in sociolinguistics. In Research methods in sociolinguistics: a practical guide, edited by Janet Holmes and Kirk Hazen. Oxford; Malden MA: Wiley Blackwell.

Holmes, J., \& Marra, M. (2017). You're a proper tradesman mate: Constructing a professional identity in construction. In Identity Struggles. Evidence from Workplaces around the World, edited by Dorien Van De Mieroop and Stephanie Schnurr. Amsterdam: John Benjamins.

Holmes, J., \& Marra, M. (2014). The complexities of communication in professional workplaces. In The Routledge handbook of language and professional communication, edited by Vijay Bhatia and Stephen Bremner. London and New York: Routledge.

Holmes, J., \& Marra, M. (2005). Narrative and the construction of professional identity in the workplace. In The sociolinguistics of narrative, edited by Joanna Thornborrow and Jennifer Coates. Amsterdam: John Benjamins.

Holmes, J., \& Stubbe, M. (2015). Power and politeness in the workplace: A sociolinguistic analysis of talk at work. Routledge: London.

Hultgren, A. K. (2017). New perspectives on language and gender: Linguistic prescription and compliance in call centres. Language in Society, 46, 671-695.

Huppatz, K., \& Goodwin, S. (2013). Masculinised jobs, feminised jobs and men's 'gender capital' experiences: Understanding occupational segregation in Australia. Journal of Sociology, 49, 291-308.

Jones, A. (2004).Social anxiety, sex, surveillance, and the 'safe' teacher. British Journal of Sociology of Education, 25(1), 53-66. 
King, B. (2018). Communities of practice. In The Routledge handbook of workplace discourse, edited by Bernadette Vine. Routledge: London.

Ku, M. (2011). When does gender matter? Gender differences in speciality choice among physicians. Work and Occupations, 38: 221-62.

Lahelma, E. (2000). Lack of male teachers: A problem for students or teachers? Pedagogy, Culture and Society, 8, 173-186.

Litosseliti, L., \& Leadbeater C. (2013). Speech and language therapy/pathology: Perspectives on a gendered profession. International Journal of Language and Communication Disorders, 48, 90-101.

Lupton, B. (2006). Explaining men's entry into female-concentrated occupations: Issues of masculinity and social class. Gender, Work and Organization, 13(2), 103-128.

Malini, M., \& Sood, K. (2016). Busting the myth of gender bias: Views from men and women primary-school trainees and teachers. Education, 3-1344, 283-296.

Marsden, S., \& Holmes, J. (2014). Talking to the elderly in New Zealand residential care settings. Journal of Pragmatics, 64, 17-34.

MacDougall, G. (1997). Caring - a masculine perspective. Journal of Advanced Nursing 25, 809-813.

Marra, M., Schnurr, S., \& Holmes, J. (2006). Effective leadership in New Zealand workplaces: Balancing gender and role. In Speaking out: The female voice in public contexts, edited by Judith Baxter and Allyson Jule. Basingstoke: Palgrave Macmillan.

McDowell, J. (2018). Men's talk in women's work: 'Doing being' a nurse. In The handbook of workplace discourse, edited by Bernadette Vine. London: Routledge.

McDowell, J. (2015a). Masculinity and non-traditional occupations: Men's talk in women's work. Gender, Work and Organization, 22, 273-291.

McDowell, J. (2015b). Talk in feminised occupations: Exploring male nurses' linguistic behaviour. Gender and Language, 9, 365-389.

McDowell, J., \& Klattenberg, R. (2018). Does gender matter? A cross-national investigation of primary class-room discipline. Gender and Education. DOI: 10.1080/09540253.2018.1458078

McEntee-Atalianis, \& Litosseliti, L. (2017). Narratives of sex-segregated professional identities. Narrative Inquiry, 27, 1-23.

McGrath, K., \& Bergen, V. (2017a). Are male teachers headed for extinction? The 50-year decline of male teachers in Australia. Economics of Education Review, 60, 159-167.

McGrath, K., \& Bergen, P. V. (2017b). Elementary teachers' emotional and relational expressions when speaking about disruptive and well-behaved students. Teaching and Teaching Education,67, 487-497.

McHoul, A. (1990). The organisation of repair in classroom talk. Language in Society, 19, 349-377.

Mills, S., \& Mullany, L. (2011). Language, gender and feminism: Theory, methodology and practice. London: Routledge.

Moosa, S., \& Bhana, D. (2017a). 'They won't take you as a man, as a real man.' Why men can'tteach young children in foundation phase. International Journal of Inclusive Education. http://dx.doi.org/ 10.1080 /13603116.2017.1390002

Moosa, S., \& Bhana, D. (2017b). Men managing, not teaching Foundation Phase: teachers, masculinity and the early years of primary schooling. Educational Review, 69(3), 366-387.

Mullany, L., \& Yoong, M. (2018). Identity and the workplace. In The Routledge handbook of workplace discourse, edited by Bernadette Vine. Routledge: London.

Mullany, L. (2014). Discourse, gender and professional communication. In The Routledge handbook of discourse analysis, edited by James Paul Gee and Michael Handford. Routledge: London.

Ochs, E.(1992). Indexing gender. In Rethinking context: Language as an interactive phenomenon, edited by Alessandro Duranti and Charles Goodwin. Cambridge: Cambridge University Press.

Powell, A., Bagilhole, B., \& Dainty, A.(2009). How women engineers do and undo gender: Consequences for gender equality. Gender, Work and Organization, 41-28.

Radford, J., Blatchford, P., \& Webster, R. (2011). Opening up and closing down: How teachers and TAs manage turn-taking, topic and repair in mathematics lessons. Learning and Instruction, 21, 625-635.

Radford, J, Bosanquet, P., Webster, R., Blatchford, P., \& Rubie-Davies, C. (2014). Fostering learner 
independence through heuristic scaffolding: A valuable role for teaching assistants. International Journal of Educational Research, 63, 116-126.

Radford, J., Bosanquet, P., Webster, R., \& Blatchford, P. (2015). Scaffolding learning for independence: Clarifying teacher and teaching assistant roles for children with special educational needs. Learning and Instruction, 36, 1-10.

Rahimi, A., \& Dastjerdi, H. V. (2012). Impact of immediate and delayed error correction on EFL learners' oral production: CAF. Mediterranean Journal of Social Sciences, 3, 45-54.

Read, B. (2008). 'The world must stop when l'm talking': Gender and power relations in primary teachers' classroom talk. British Journal of Sociology of Education, 29, 609-621.

Ridley, J., Radford, J., \& Mahon, M. (2002). How do teachers manage topic and repair? Child Language Teaching and Therapy, 18(1): 43-58.

Rhoton, L. A. (2011). Distancing as a gendered barrier. Gender and Society, 25(6), 696-716.

Rubie-Davies, C., Blatchford, P., Webster, R., Koutsoubou, M., \& Bassett, P. (2010). Enhancing student learning? A comparison of teaching and teaching assistant and interaction with pupils. School Effectiveness and School Improvement, 21, 429-449.

Sargent, P. (2000). Real men or real teachers? Contradictions in the lives of men elementary Teachers. Men and Masculinities, 2(4), 410-433.

Schegloff, E., Jefferson, G., \& Sacks, H. (1977). The preference for self-correction in the organization of repair in conversation. Language, 53(2), 361-382.

Schnurr, S. (2013). Exploring professional communication. Abingdon: Routledge.

Skelton, C. (2002). The 'feminisation of schooling' or 're-masculinising' primary education? International Studies in Sociology of Education 12(1), 77-96.

Skelton, C. (2003). Male primary teachers and perceptions of masculinity. Educational Review, 55, 195-209.

Skelton, C. (2009). Failing to get men into primary teaching: a feminist critique. Journal of Education Policy, 2439-54.

Spilt, J., Helma, K., \& Suzanne, J. (2012). Are boys better off with male and girls with female teachers? A multilevel investigation of measurement invariance and gender match in teacher-student relationship quality.Journal of School Psychology, 50, 363-378.

Simpson, R. (2004). Masculinity at work: The experiences of men in female dominated occupations. Work, Employment and Society, 18, 349-368.

Sinclair, J., \& Coulthard, M. (1975). Towards an analysis of discourse. Oxford: Oxford University Press.

Thornton, M., \& Bricheno, P. (2006). Missing men in education. Trentham Books: Stoke on Trent.

Van der Vleuten, M., Jaspers, E., Maas, I., \& van der Lippe, T. (2016). Boys' and girls' educational choices in secondary education: The role of gender ideology. Educational Studies, 42, 181-200.

Vehkakoski, T. (2010). To correct or not correct the erroneous utterances of children: Teacher-initiated organisation of repair in the L2 pre-primary education classroom. European Early Childhood Education Research Journal, 18(2), 125-138.

Vervecken, D., \& Hannover, B. (2015). Yes I can! The impact of gender fair descriptions of traditionally male occupations on children's perceptions of job status, job difficulty and vocational self-efficacy beliefs. Journal of Vocational Behaviour, 82, 208-220.

Warwick, J., Warwick, P., \& Hopper, B. (2012). Primary teacher trainee perspectives on a male-only support group: Moving male trainee teachers beyond the 'freak show'. Teacher Development, 16, 55-76.

Wasserman, V., Dayan, I., \& Ben-Ari, E. 2018. Upgraded masculinity: A gendered analysis of the debriefing in the Israeli air force. Gender and Society, 32, 228-251.

Wenger, E. (1998). Communities of practice: Learning, meaning, and identity. Learning in doing. Cambridge: Cambridge University Press.

Williams, C. (1993). Doing women's work: Men in non-traditional occupations. Sage: London. 